\title{
Clustering of oral symptoms versus radiation-induced apical periodontitis - author reply
}

\author{
Geert M. G. Hommez • Gert O. De Meerleer • \\ Wilfried J. De Neve • Roeland J. G. De Moor
}

Received: 25 October 2012 / Accepted: 22 November 2012 /Published online: 2 December 2012

(C) Springer-Verlag Berlin Heidelberg 2012

\section{Dear Editor,}

We thank Dr. Ribeiro for his interest in our paper. However, it seems that Dr. Ribeiro and colleagues misinterpreted our data. Nowhere in our publication have we mentioned a direct radiogenic destruction of teeth. In fact, others have studied this and gave evidence of the contrary [1].

What we found in an earlier study [2] was that despite of a very high caries rate in the study group, the prevalence of apical periodontitis was not increased when compared to a general population. We hypothesized that changes in bony tissue following irradiation could partly be of influence in this observation.

Consequently, we wanted to study the prevalence of apical periodontitis in relation to the radiation dose, as we thought that bone changes in the radiation field could possibly influence the genesis and expansion of apical periodontitis. We found that of all teeth in the studied population, the radiation dose was significantly higher on teeth with apical periodontitis.
The observations made in this study could possibly be caused by changes in irradiated bone and changes in microflora of the mouth (and the root canals). Other studies, as mentioned in our paper, gave evidence of bone changes following radiotherapy. That cannot be denied.

We never stated that radiotherapy causes tooth destruction and this cannot be the conclusion of this study.

\section{References}

1. Kielbassa AM, Hinkelbein W, Hellwig E, Meyer-Lückel H (2006) Radiation-related damage to dentition. Lancet Oncol 7:326-329

2. Hommez G, De Meerleer G, Vakaet L, De Neve W, Vermeersch H, De Moor R (2008) Prevalence of apical periodontitis and associated coronal factors in head and neck irradiated patients. Endodontic Pract Today 2:105-116

G. M. G. Hommez $(\bowtie) \cdot$ R. J. G. De Moor

Department of Operative Dentistry and Endodontology,

Dental School, Ghent University Hospital,

Ghent University, De Pintelaan 185,

9000 Ghent, Belgium

e-mail: geert.hommez@ugent.be

G. O. De Meerleer • W. J. De Neve

Department of Radiotherapy, Ghent University Hospital,

Ghent University, Ghent, Belgium 